\title{
Cultural Resilience of Social-ecological Systems in the Nenets and Yamal- Nenets Autonomous Okrugs, Russia: A Focus on Reindeer Nomads of the Tundra
}

\author{
Bruce C. Forbes $^{1}$
}

\begin{abstract}
Empirical data on resilience in social-ecological systems (SESs) are reviewed from local and regional scale case studies among full-time nomads in the neighboring Nenets and Yamal-Nenets Autonomous Okrugs, Russia. The focus is on critical cultural factors contributing to SES resilience. In particular, this work presents an integrated view of people situated in specific tundra landscapes that face significantly different prospects for adaptation depending on existing or planned infrastructure associated with oil and gas development. Factors contributing to general resilience are compared to those that are adapted to certain spatial and temporal contexts. Environmental factors include ample space and an abundance of resources, such as fish and game (e.g., geese), to augment the diet of not only the migratory herders, but also residents from coastal settlements. In contrast to other regions, such as the Nenets Okrug, Yamal Nenets households consist of intact nuclear families with high retention among youth in the nomadic tundra population. Accepting attitudes toward exogenous drivers such as climate change and industrial development appear to play a significant role in how people react to both extreme weather events and piecemeal confiscation or degradation of territory. Consciousness of their role as responsible stewards of the territories they occupy has likely been a factor in maintaining viable wildlife populations over centuries. Institutions administering reindeer herding have remained flexible, especially on Yamal, and so accommodate decision-making that is sensitive to herders' needs and timetables. This affects factors such as herd demography, mobility and energetics. Resilience is further facilitated within the existing governance regimes by herders' own agency, most recently in the post-Soviet shift to smaller, privately managed herds that can better utilize available pastures in a highly dynamic environment experiencing rapid socio-economic, climate and land use change.
\end{abstract}

Key Words: Climate change; Hydrocarbon extraction; Nomadism; Rangifer tarandus; Siberia; Stewardship; West Siberian Tundra

\section{INTRODUCTION}

Tundra Nenets nomadism is well known within and outside Russia for both the high quality of the intensive or 'close' reindeer herding (sensu Ingold 1980) techniques used and the iconic imagery of a long-distance migratory lifestyle that has all but vanished from most other sectors of the circumpolar Arctic (Stammler 2005a). Nenets reindeer herding within the tundra zone straddles the Polar Ural Mountains, its rangelands encompassing $>70 \%$ of the Nenets Autonomous Okrug (NAO) of the East European Arctic and the Yamal-Nenets Autonomous Okrug (YNAO) of West Siberia (Stammler $2005 a$, Rees et al. 2008). As neighboring federal districts they share key common characteristics. These include the presence of large semidomestic reindeer herds managed by the indigenous Nenets, ongoing large-scale hydrocarbon development and climate warming in the past few decades (Rees et al. 2008, Forbes et al. 2009). Other indigenous peoples practice reindeer herding on the tundra pastures of these regions, such as Komi-Izhemtsy and Khanty in YNAO and Komi-Izhemtsy in NAO, but the present analysis will be limited to tundra Nenets. Ecological drivers are certainly important, and there is evidence for extensive terrestrial and freshwater degradation across these regions from anthropogenic disturbance. Specifically, there has been a shift from shrub- to graminoid-dominated tundra that is persistent over sizable areas in the vicinity of active and abandoned oil and gas infrastructure (Forbes et al. 2009, Kumpula et al. 2011, 2012). At the same time the availability of fish, a critical source of protein for herders during summer migration, has decreased. This is a result of direct and indirect impacts from road, railway, and bridge construction combined with increasing competition from new workers, who fish in rivers and lakes during their free time (Forbes et al. 2009). Symptoms of warming air temperatures commented on by herders in recent years include earlier break up of rivers and lakes in the spring, later freeze up in autumn, more frequent and intensive rainon-snow events in winter, and hotter summers with a greater degree of insect harassment (Rees et al. 2008, Forbes and Stammler 2009, Forbes et al. 2009, Bartsch et al. 2010).

Observers have often commented on the apparent flexibility of the Nenets when faced with a wide range of exogenous forces during the Soviet and post-Soviet eras (Golovnev and Osherenko 1999, Stammler 2002, Tuisku 2003, Zenko 2004). The Yamal Nenets social-ecological system (SES), in particular, has stood out as being resilient in the face of extreme shocks and pressures in the past 20-30 years (Forbes et al. 2009) and its tundra nomads are generally considered by other herding cultures within modern Russia to be the 'real' reindeer 
Fig. 1. Hydrocarbon resources of Arctic Europe and West Siberia. Permission to use granted by Sherpa Konsult as, Oslo, Norway.

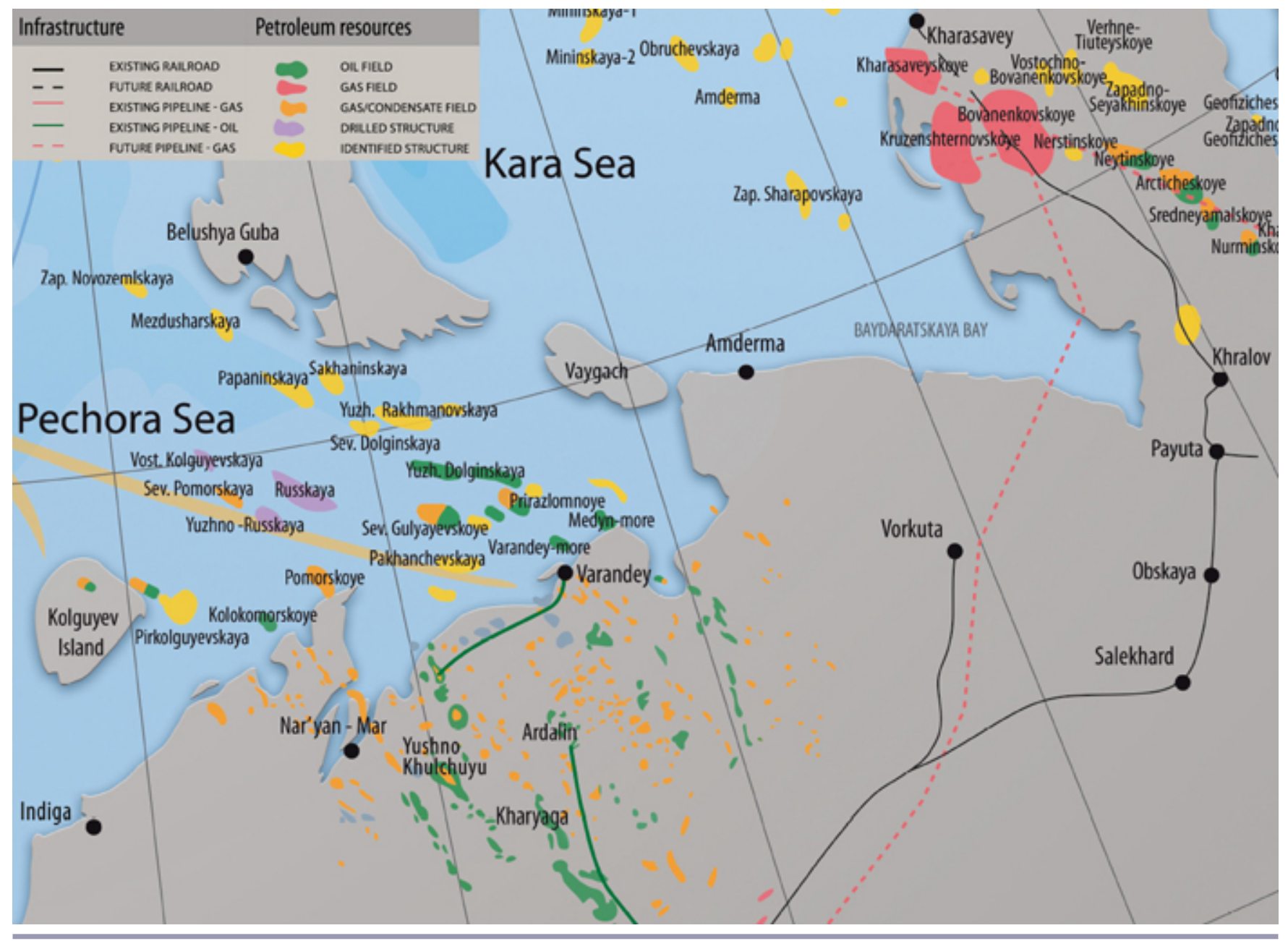

herders (Stammler 2005a). Within this context, this paper seeks to address a few key questions. Firstly, while Nenets SESs have adapted well to a variety of pressures over the last few decades, can we identify cultural aspects of resilience that have helped them to persist over the decades, and perhaps centuries? If so, are there marked differences in the acknowledged markers of cultural resilience between contemporary Nenets SESs in neighboring federal districts? Finally, to what extent does human agency contribute to resilience and over which temporal and spatial scales?

Crane (2010:2) considers "long-term resilience as a culturally defined experience, exploring the synergies and tensions between resilience as an analytical scientific lens and resilience as a 'normative' cultural process. Note that 'normative' is used to connote socially defined and held values and ideals regarding desirability or propriety of a circumstance or practice, rather than the objective empirical conditions themselves. Collectivity is a key aspect of this use of 'normative' and distinguishes it from 'subjective', which emphasizes individual experience and positionality." Thus, according to Crane (2010), cultural resilience is "the ability to maintain livelihoods that satisfy both material and moral (normative) needs in the face of major stresses and shocks; environmental, political, economic, or otherwise." This definition fits well for the purposes of the present analysis given the suite of stresses and shocks to be addressed.

This article will address first factors both affecting and contributing to general resilience, then look more closely at cultural components of resilience that fall under the loose rubrics of stewardship (sensu Chapin et al. 2010) and worldview (sensu McIntosh et al. 2000). In addition, careful attention will be paid to human agency. Davidson (2010:1145) considers human agency as "the most contentious wrinkle in the application of an ecological framework to social systems". 
She suggests that, "socio-ecological analyses that ignore agency, however, are woefully insufficient. Agency encompasses both individual-level action, premised on confidence among autonomous and able members of society that change is possible, and collective agency, expressed in the cultural, infrastructural, and communicative resources that enable collective action." Collective action features prominently in Nenets SESs, as does 'collectivity' in the definition of cultural resilience provided by Crane (2010). As such, these will also be discussed in light of the findings and used for framing the conclusions.

\section{MATERIALS AND METHODS}

\section{Study areas}

Research was conducted in association with two hydrocarbon fields in the Russian Arctic. These two cases were chosen, because they represent: (1) the two key Federal districts in modern Russia containing proven onshore oil and gas deposits under development, with oil transported via both tanker and pipeline from Varandey terminal in NAO and gas via pipeline from Yamal Peninsula in YNAO (Kumpula et al. 2011, 2012) (Fig. 1, see also Figs. 3 and 5); (2) the two most productive regions for reindeer herding in terms of total numbers of animals (Forbes and Kumpula, 2009); and (3) neighboring regions where both reindeer management (Fig. 2) and the extent of engagement with the hydrocarbon extraction industry differ substantially (Stammler and Wilson, 2006, Stammler and Peskov, 2008, Kumpula et al. 2011). The gas field at Bovanenkovo, located on central Yamal Peninsula in northwest Siberia (YNAO) $\left(70^{\circ} 20^{\prime} \mathrm{N}, 68^{\circ} 00 \mathrm{E}\right)$, is one of the largest in all of Russia in terms of proven reserves (Figs. 3, 4). Bovanenkovo Gas Field (BGF) is not yet under full production, but opened at the end of 2012 (Kumpula et al. 2012). Nonetheless, infrastructure is rapidly expanding, coupled with a massive influx of shift workers (Forbes et al. 2009). Geological surveys of the gas field began to accelerate in 1980s and the first construction phase started in 1987. The second research area, Toravei oil field, is located on the Varandei Peninsula $\left(68^{\circ} 66^{\prime} \mathrm{N}, 58^{\circ} 33^{\prime} \mathrm{E}\right)$ in NAO (Fig. 5). In 2001 an offshore oil terminal was opened in Varandei and soon after oil pumping started from Toravei field (Kumpula et al. 2011). Supplementary historical information and future plans for drilling sites, roads/railways, and pipelines in each region were obtained from local administrations and workers of the oil and gas industry.

Administratively, large differences in the two neighboring Nenets regions have existed for several centuries. NAO was subjugated by Russia in the late 1500s, whereas Yamal remained relatively untouched by the Russian administration until the 1930s (Stammler 2005a). NAO herders became baptized and were given Russian names in the early-mid 1800s, whereas the Yamal herders have never been baptized and kept their traditional Nenets names until quite recently. Although Yamal Nenets herders hardly constitute an 'ethnographic' isolate, they clearly succeeded in preserving
Fig. 2. Reindeer herding territories (shown in white) of the East European Arctic and West Siberia.

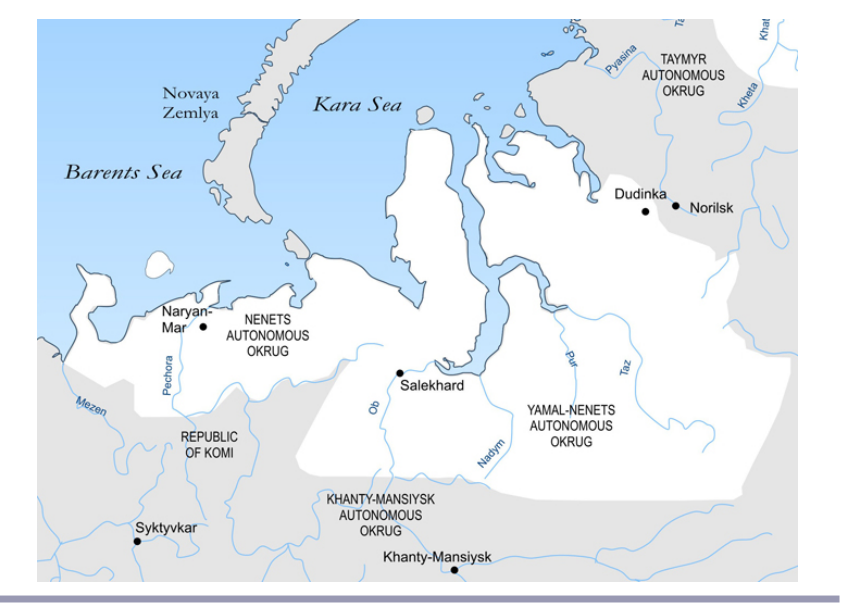

Fig. 3. Hydrocarbon fields, infrastructure and collective reindeer management (sovkhoz) territories on Yamal Peninsula, West Siberia.

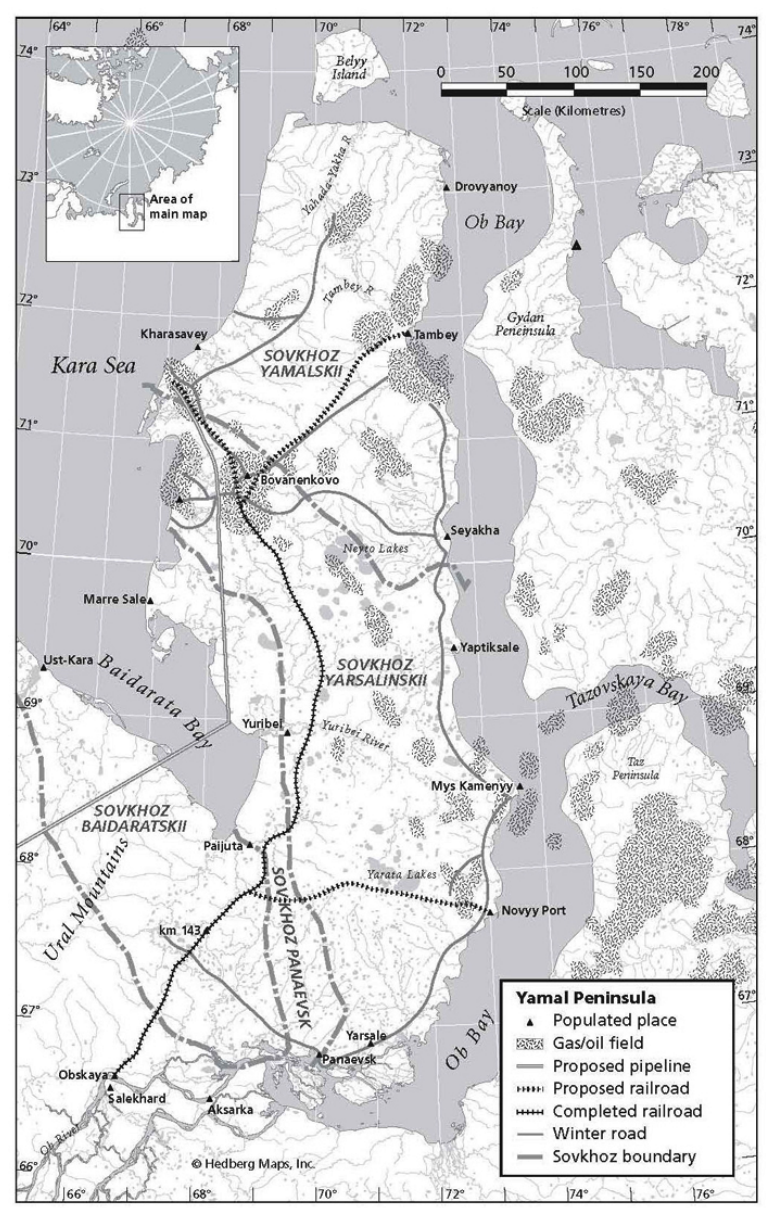


Fig. 4. Examples of modern nomadic routes (solid red lines) on Yamal Peninsula in relation to the gas fields at Bovanenkovo and Kharasavei port and the ObskayaBovanenkovo railway (dashed black line).

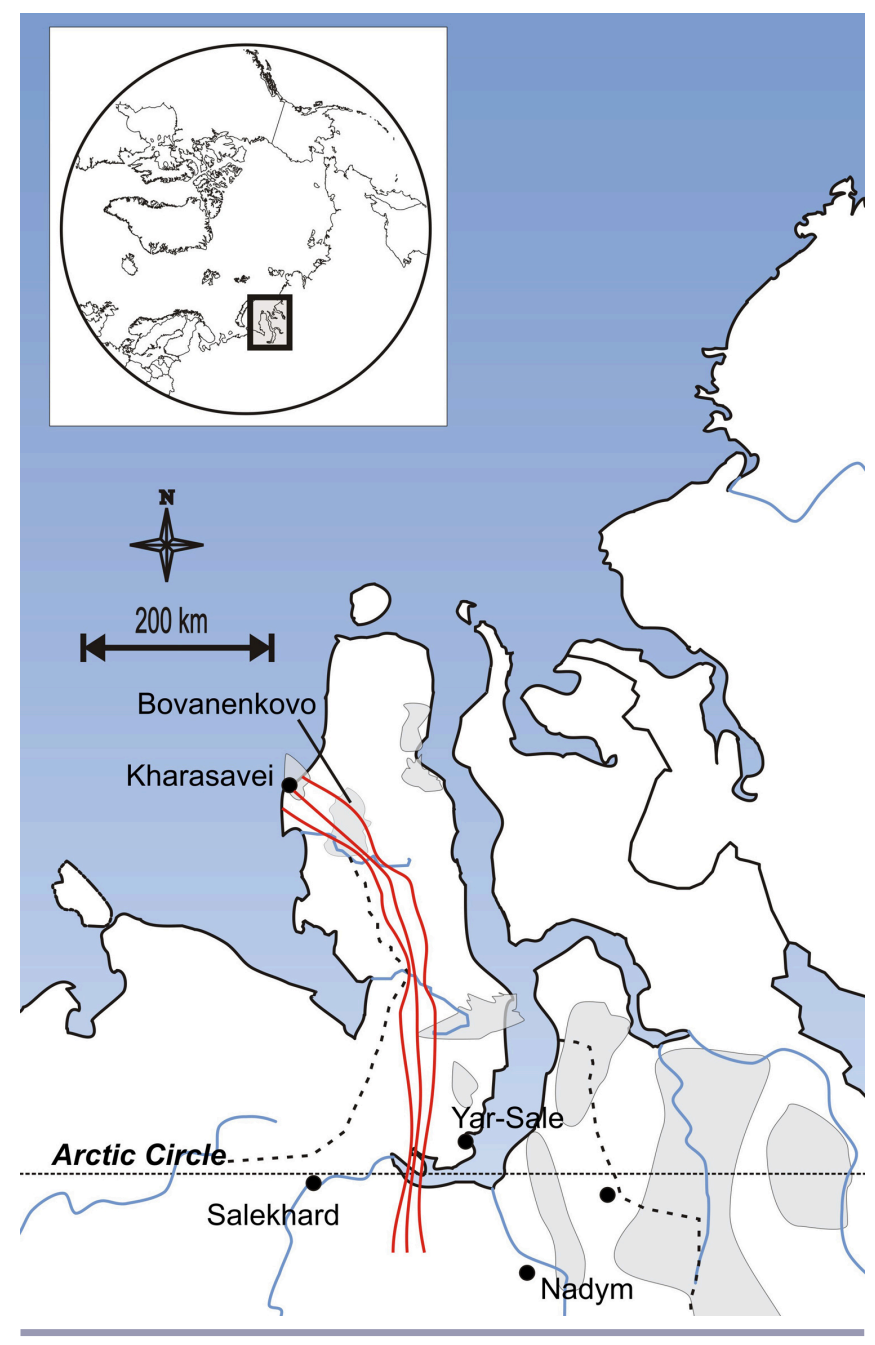

much more vitality and cultural strength by the time Soviet modernization hit them hard (Stammler 2002, 2005a), while a lot of this vitality was already gone among their counterparts in the NAO due to a much longer record of interacting with Russians.

\section{Approach}

Intensive participant observation with Nenets nomads is coupled with a literature review. The overall time spent with participant observation among all groups from March 2004 to July 2007 was 33 person months, plus a stakeholder assessment workshop (sensu Carpenter et al. 2005) in December 2007. Additional input was provided in March and November 2008 in conjunction with follow-up discussions to finalize the principles for coexistence first drafted at the stakeholder assessment workshop (Stammler et al. 2009). Another two person months of fieldwork on Yamal Peninsula took place in July 2010 and July 2011. Historical profiling (sensu Carpenter et al. 2005) via participant observation entailed taking part in every aspect of daily life through all seasons in YNAO and summer and winter in NAO. Florian Stammler and Nina Meschtyb performed most of the participant observation fieldwork, joined for shorter periods by the author in both regions. Roza Laptander conducted fieldwork with the author in 2010. The present contribution offers a more theoretical perspective, whereas the empirical data to support it may be found elsewhere (cf. Meschtyb et al. 2005, Stammler 2005a, 2008, 2010, 2011, Forbes et al 2009, 2011, Kumpula et al. 2010, 2011, 2012).

Fig. 5. Oil fields and infrastructure in the Varandei region, Nenets Autonomous Okrug. Toravei field is indicated by the high density of tracks from off-road vehicle traffic in the lower center portion of the map.

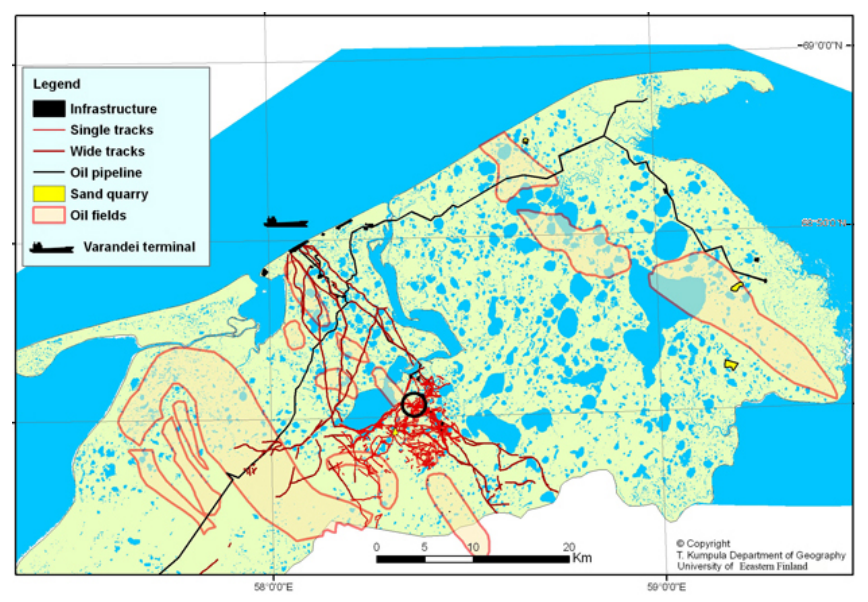

In both YNAO and NAO, land is divided between the successor reindeer herding enterprises of Soviet State and Collective Farms, sovkhozy and kolkhozy, which in turn consist of individual work-teams, called brigades. Especially on Yamal Peninsula herders' migration routes are long, some up to $600 \mathrm{~km}$ and typically in $8-20 \mathrm{~km}$ wide migration corridors. Within the Yarsalinskii sovkhoz we focused on three 'northern brigades' or collective herd management units for in depth participant observation and interviews. These three encompass herds that have either direct or indirect contact with the main oil and gas infrastructure at BGF. The aim was to learn from the contrast provided by herding units that have lost considerable amounts of their territory versus those that have lost little. One brigade (no. 4) was accompanied during its migration through BGF in July, and another one (no.2) passing $\approx 20 \mathrm{~km}$ south of it. A third (no. 8) also crosses BGF, but was accompanied outside of the immediately affected area 
for $200 \mathrm{~km}$ of their migration in autumn 2007 toward the slaughterhouse at Yar-Sale (Figs. 3, 4). Privately managed herds in the vicinity of BGF were included in the analysis. The number of privately owned animals has increased steadily from 30\% in 1965 through the post-Soviet era to the present $80 \%$ (Forbes et al. 2009). Their interests are generally poorly represented in development decisions since most of them do not belong to a registered land-using entity (Kumpula et al. 2011), however they are essential to an overall understanding of resilience. Each nomadic group consisted of 10-90 people comprised of two to nine nuclear families managing from 3000 to 8000 animals.

In NAO within the Yerv reindeer herding enterprise we focused on two out of seven brigades because their migration routes went directly through the main oil field under active development at the time of the fieldwork (2006). Fig. 6-9 include images of Nenets households migrating through heavily industrialized areas. Yerv's brigades' migration regime is more complex than on Yamal and many brigades encounter oil infrastructure and settlements several times annually. Instead of moving along corridors they follow a complicated pattern shaped of multiple figure-8's formed after the demise of the Soviet Union. Crucial variables determining these migration routes are vegetation, local topography, industrial sites, and fishing lakes (Kumpula et al. 2011, 2012).

\section{RESILIENCE: GENERAL FACTORS, EXOGENOUS DRIVERS, AND SPECIFIC CULTURAL ASPECTS}

\section{General factors}

Several factors contribute to the general resilience of Nenets SESs. Environmental factors include ample space for practicing long-distance reindeer migration and an abundance of resources, such as fish and game (e.g., geese). The latter augment the diet of not only the migratory herders, but also residents from coastal settlements, who typically have relatives among the nomadic tundra population. Fish and game thus provide alternative sources of protein during the late spring and summer migration, when herders prefer not to slaughter reindeer so as not to waste their valuable hides, which are in the process of molting at that time. Regarding space, at $750,300 \mathrm{~km}^{2}$ the total territory of YNAO is more than four times that of NAO $\left(176,700 \mathrm{~km}^{2}\right)$. A significant proportion of YNAO is forested territory, whereas NAO lies primarily within the tundra zone.

Relative to other regions within Russia (Krupnik 2000, Stammler 2005a), and their counterparts in Fennoscandia (Forbes et al. 2006), the institutions governing reindeer herding have remained benign concerning day-to-day and month-to-month herd management. Even though administrators tend to see herding mainly as the "production of meat and antlers" (Tuisku 2002b:193), decisions can still be made quickly and efficiently and herds are not micromanaged for meat production to a degree that would reduce herders' ability
Fig. 6. Part of a caravan of draught animals from a large brigade crossing the Se-yakha River in the midst of the Bovanenkovo Gas Field (BGF), July 2011. Photo by B.C. Forbes.

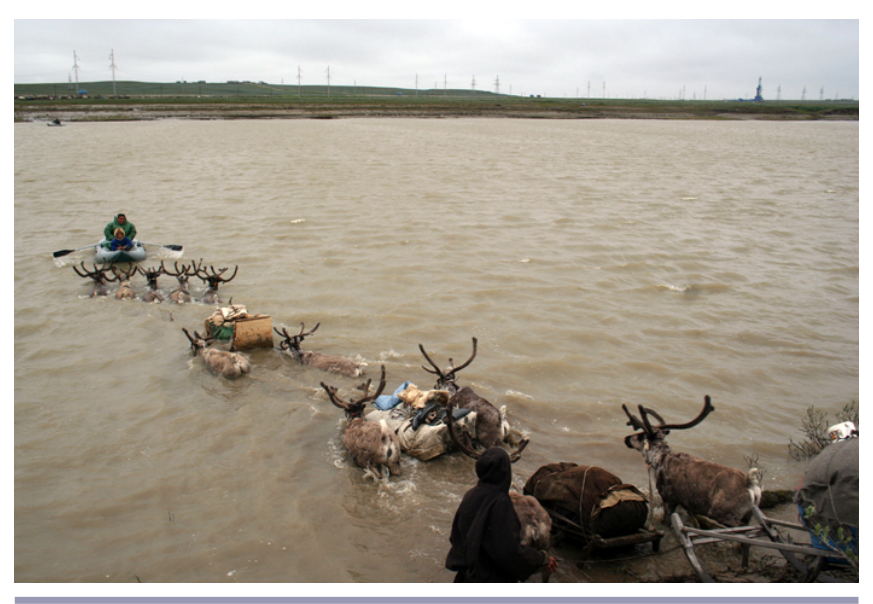

Fig. 7. Reindeer resting among infrastructure during migration through BGF, July 2011. Photo by B.C. Forbes.

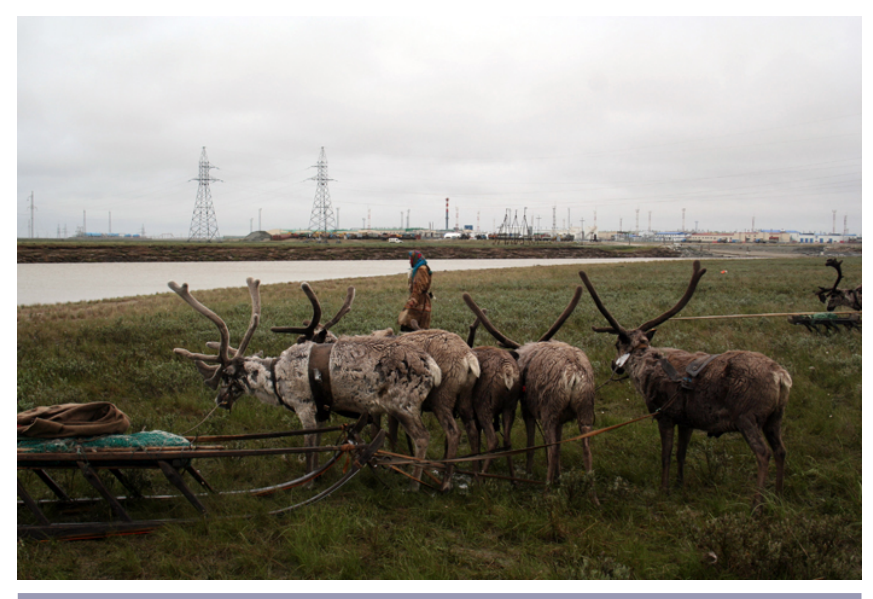

to adapt to change. This is especially true on Yamal Peninsula compared to NAO, where the modern institutional arrangement accommodates decision-making that is sensitive to herders' needs and timetables. One of the key aspects of the Soviet-era administration of Yamal is that they did not restrict private ownership of animals. In NAO privatization of kolkhozy and sovkhozy was mostly nominal as they were renamed but their structure remained essentially intact (Tuisku $2002 b$ ). Other regions had lost most of their own adaptive capacity because it was effectively destroyed by the intrusion of the Soviet system, confiscation of private property, and forcefully sedentarizing nomads (Krupnik 2000, Gray and Stammler 2002). On Yamal, this influence was comparably 
less pronounced because local Soviet bureaucrats succeeded to incorporate Nenets needs while still showing conformity to central Soviet policies on paper (Stammler 2005a). The essence of this informal contract between the Nenets and their Soviet administrators is encapsulated by a pointed comment to a herder from an administrator: "You pretend to work on our terms, and we pretend that we believe you " (Forbes et al. 2009, Supp. Inf.).

Fig. 8. Nenets camp next to a new drill rig in BGF, July 2011. Photo by B.C. Forbes.

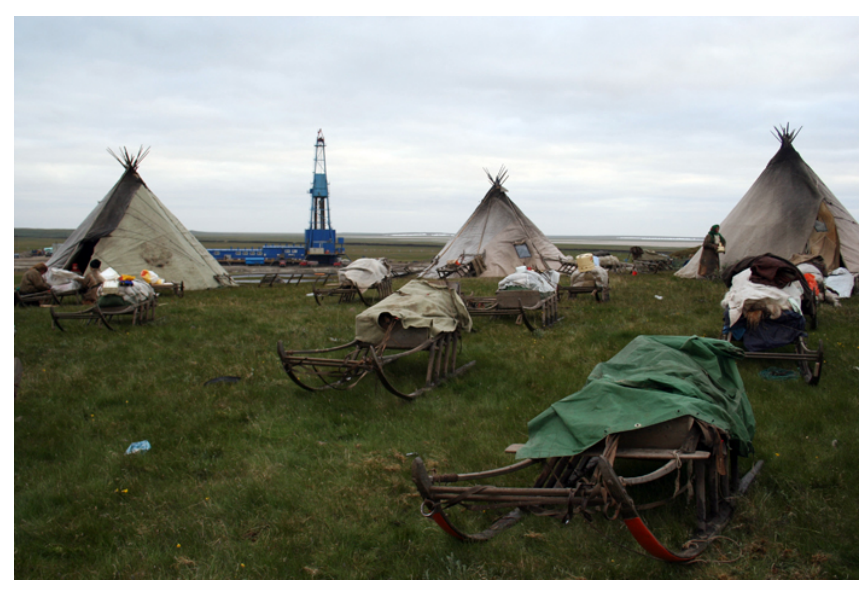

Fig. 9. Nenets family bringing fresh reindeer meat to barter at BGF, July 2005. Photo by B.C. Forbes.

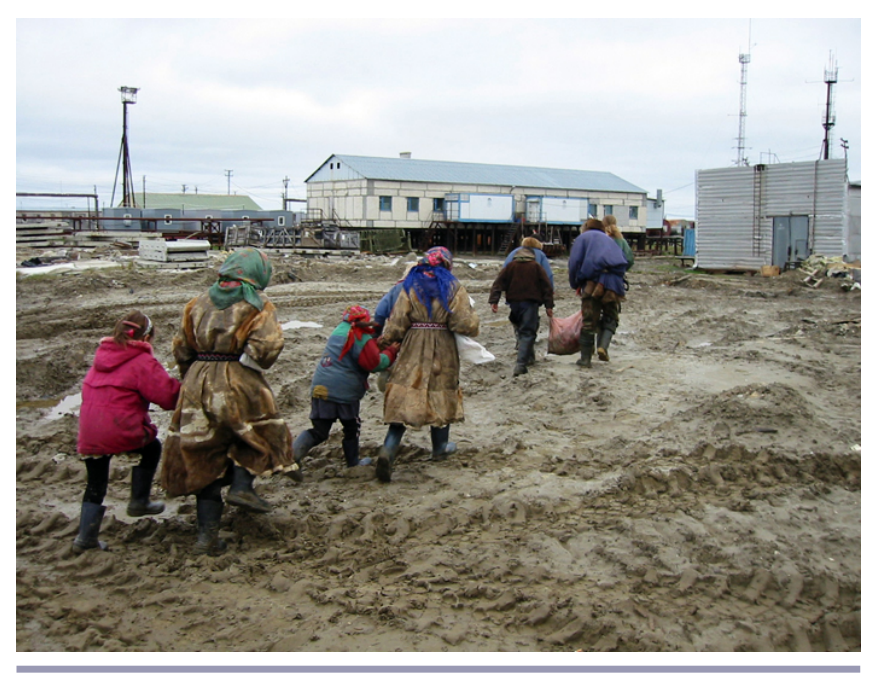

Resilience is further facilitated within the existing governance regimes by herders' own agency (cf. Stammler 2011), most recently in the post-Soviet shift to smaller, privately managed herds that can better utilize available pastures in a highly dynamic environment experiencing rapid socio-economic, climate, and land use change. Although Nenets rangelands are vast, mobility is not dependent on outside subsidies of energy, such as motorized transport and petroleum products since herders continue to use their traditional reindeer-drawn sledges (Stammler 2002). There are probably more snowmobiles in the tundra in NAO than on Yamal, but reindeer remain the most important means of transportation during migrations, hunting and fishing trips when away from settlements (Stammler 2002, Tuisku 2002b). On Yamal, the number of privately managed animals has more than doubled since the breakup of the Soviet Union (Yuzhakov 2006) as herders opt out of the restrictions imposed by the collective system or try to avoid the various ramifications of spreading infrastructure development. This constitutes a use of 'interstitial' space, described by Anderson (2006) as a mode of weaving between available patches within increasingly fragmented and regulated territories. The institutional form of the private units in Yarsalinskii sovkhoz, focus of the present analysis, is less structured than that found in the Yamalskii sovkhoz to the north, where the obshchina movement has been pronounced, as discussed at length by Stammler (2005b). An obshchina on Yamal can be simply "a registered union of private herders who wish to sell produce jointly" (Stammler 2005a:169). However, a more nuanced definition positions the Yamal obshchina as, "a social unit that helps strengthen the collectivity of an indigenous community when it becomes an administrative body and seeks to claim land against another actor that is already (or potentially) more powerful (Stammler 2005b:114).

So far, relations between neighboring collective and private herding entities remain mutually supportive. Furthermore, as the population of tundra nomads continues to grow, local control over herd demography is likely to contribute to longterm resilience since herders can make decisions concerning energetics (e.g., numbers of breeding females vs. castrated males) based on their own needs. Just as the institutions governing herd movements during migration remain flexible, so do those relevant for herd demography. Thus, overall herd size, age, and gender distribution, and purposeful castration of bulls remain largely in the hands of herders.

\section{Exogenous drivers}

An important exogenous driver testing cultural resilience in Nenets SESs has been the degree of sedentarization among the tundra nomads. At the end of the 1950s a massive Soviet program to sedentarize the Nenets took place, albeit to a greater extent in NAO (Tuisku 2001) than in YNAO (Golovnev and Osherenko 1999, Stammler 2005a). The program coincided with the introduction of shift labor in NAO, whereby one shift of herders would remain in the village while another was on the tundra. Tuisku (2001:45) observes that, "the shifts were derived from the former brigades originally established under collectivization, such that each brigade was divided into two shifts. Despite the relocation of women and children from the 
tundra, migration persisted because men continued to migrate with their herds." This paralleled efforts by the Soviet state to sedentarize reindeer peoples in other regions (Vitebsky and Wolfe 2001, Ssorin-Chaikov 2003). In this context, Vitebsky (2005:192) laments the brutal efficiency of what he refers to as the "denomadization of women" among the Eveny in northeastern Siberia. As the pace of gas development in YNAO picks up, conflicts centering on sedentarization may increase since tundra nomads tend to resist state efforts at relocation into regional settlements (Stammler 2008). On Yamal Peninsula, the tundra populations of people and herded reindeer have actually grown in recent years in spite of such efforts (Stammler 2008, Forbes et al. 2009).

Other exogenous drivers that exert influence regionally yet are locally highly variable in terms of their importance are climate, which is generally manifest as weather to herders, and oil and gas development. Nenets nomads whose territories lie within the pathways of ongoing and planned developments understandably tend to rank hydrocarbon extraction as the issue of greatest concern for the future (Forbes and Stammler 2009, Kumpula et al. 2011, 2012). Key factors include the incremental loss of pastures and fishing resources to industry, changes in subsidies, and real or perceived obstructions to the free movement of animals (Rees et al. 2008, Forbes et al. 2009, Kumpula et al. 2012) (Fig. 6). Yet industrial development is still only one among the various issues facing reindeer herders and administrators. For most herders the biggest concern is their basic economic survival and wellbeing from day to day, year to year (Tuisku 2003, Stammler 2005a). However, weather conditions undeniably have a major impact on Nenets SESs and year-round air temperatures have already increased $\approx 2^{\circ} \mathrm{C}$ over the past 30 years or so (NASA-GISS 2013). During winter, there appears to be in increase in the frequency and intensity of rain-on-snow events (Bartsch et al. 2010). In such instances ice covers the snow, and sometimes the ground, and the herders are forced to move quickly and often over great distances to find more accessible pastures (Tuisku 2002c, Bartsch et al. 2010). Precipitation is expected to increase, with rainfall representing a greater proportion than at present (Callaghan et al. 2011). Snow cover depth has already increased in recent decades whereas its duration has decreased and the overall growing season has lengthened (Bulygina et al. 2009, 2011, Zeng et al. 2013). Implications for reindeer herding include increases in shrub height and cover (Rees et al. 2008, Forbes et al. 2010, Macias-Fauria et al. 2012), decreases in lichen cover due to competition (Chapin et al. 1995, Cornelissen et al. 2001) and ongoing trampling by reindeer (Forbes and Kumpula 2009), later autumn freeze-up, earlier spring thawing of rivers and lakes (Rees et al. 2008, Forbes et al. 2009, Xu et al. 2013), and drying of lakes and wetlands (Smith et al. 2005, Rees et al. 2008).

\section{Specific cultural aspects}

A critical aspect of cultural resilience in Nenets SESs is that tundra nomads have intimate relationships with all of the animals they manage. Obviously, this includes reindeer, but also extends more generally to other economically and socially important forms of wildlife and their respective habitats through rituals addressed to the 'master of the game', proper consideration for the spirits of fish and the water bodies, and other practices (Stammler 2010). Fish is a critical resource all year round, especially during the long summer migration. Particularly among older people, there is a consciousness about maintaining fish populations. Timing, location, duration of fishing efforts are all therefore carefully considered. Although hunting has decreased greatly in importance since Soviet times, the spring hunt for geese remains as a highly significant social event on the annual calendar. The reason is "because it provides an opportunity for sedentarized Nenets to join their nomadic relatives in the tundra" (Stammler 2010:225). The great significance that Nenets herders attach to their animals serves as a basis for what Stammler (2010:236) refers to as a "model for cultural integrity in their humanenvironment relations". Following from this, a spirit of stewardship permeates fishing, hunting, and herding practices day in and day out, year after year. As Stammler (2010:225) observes, reindeer serves as the supreme identity marker for the Nenets because, "only reindeer have personhood in individual partnerships, and symbiotic domesticity is enacted only between such animal persons and human persons." However, it must be emphasized that overall animal diversity is critical to the long-term maintenance of Nenets socialcultural-ecological systems. In this model, which emphasizes stewardship, "it is the respectful approach of humans to their animals that generally distinguishes successful herders from unsuccessful ones" (Stammler 2010:236).

Stewardship in the context of herding is especially important because, despite widespread reports of 'overgrazing' and pasture degradation (Podkorytov 1995, Jernsletten and Klokov 2002, Lavrinenko and Kulugina 2002, Zenko 2004, Kryazhimskii et al. 2011), herders remain confident in their abilities to manage the reindeer as long as they retain unfettered access to pastures and fish stocks remain viable. According to herders from Yamal, fish populations have begun to return to lakes and rivers in the vicinity of BGF, providing a measure of cautious optimism (Kumpula et al. 2012). One common though controversial principle is the conviction that through application of rangeland management principles the reindeer population can and should be kept at some optimum 'carrying capacity' (Stammler 2005a, Forbes and Kumpula 2009, Rees et al. 2008). The carrying-capacity model implies a highly economic approach to reindeer herding, aimed at increasing productivity, rationalizing herding labor, and standardizing production (Rees et al. 2008). Such models tend to discount or ignore the role played by 
human agency. As will be discussed below, tundra dwellers are generally not passive receptors for endogenous and exogenous drivers, but typically have developed adaptive responses to many types of variability that they have experienced either in recent decades (e.g., hydrocarbon extraction, changes in subsidies, and shifts in pasture vegetation composition and structure) or over centuries (e.g., extreme weather events, climate change).

Another key to cultural resilience is an accommodating worldview, or cultural schema, through which social memories are transferred and interpreted (McIntosh et al. 2000). This worldview is manifest in terms of nomads' attitudes and actions with regard to the environment, oil and gas development, and the future. For Nenets, in many respects environmental 'change' is perceived as normal, and the common perception is that each year is different. Examples include 'extreme' weather scientists tend to associate with climate change (Forbes and Stammler 2009). Even if strategies are honed over generations to buffer against severe losses, it is understood and accepted that extreme events can and will occasionally impart large-scale mortality (e.g., 25\%) within herds (Forbes and Stammler 2009, Bartsch et al. 2010). Expressions of this attitude are found also in light of recent intrusions from industrial oil and gas development. Most herders met during field research and in a stakeholder workshop were in favor of oil and gas extraction and remain ready to engage so that development proceeds on their terms, even if the experience to date has proven extremely challenging (Stammler et al. 2009, Forbes et al. 2009). Among nomads on Yamal Peninsula there is no major resistance against industrial development but, rather, there is an expressed will to coexist (Stammler 2011:251). Despite rumors in NAO that money has ended up in the pockets of management personnel, "herders have not complained, although they have criticized that money is not used for investigations for the future" (Tuisku 2003:459). Similarly, while damage from off-road vehicles has been extensive and too much land has been occupied after agreements were made (Tuisku 2003, Kumpula et al. 2011), herders tend to believe that oil workers do not harm the environment on purpose (Tuisku 2002a). In the end, however, tundra herders in NAO remain somewhat skeptical about the process of development, have real fears, and are appropriately concerned about the status of the environment (Tuisku 2002a). On Yamal there is a strong sense of fear and pessimism among fishers as well as reindeer herders that when it comes to future development of offshore resources, particularly in the Ob estuary, mutual coexistence with gas development may be unrealistic (F. Stammler, personal communication).

Concerning the future, relative to populations in many other regions of the Russian Far North, Yamal tundra Nenets nomads continue to have large families and most children continue to choose to make their life on the tundra as reindeer herders. This is the case even though the skills involved cannot be learned in school and requires intensive and long-term mentoring within a collective acting network of family and friends (Ulvevadet and Klokov 2004). Both younger and older herders agree that to be able to live on the tundra one has to love the tundra. According to one herder, "If you do not live on the tundra when you are a child, you will not love the tundra as you should. A boy who comes to the tundra for the first time when he is sixteen sees the tundra as a harsh environment and not as a home" (Tuisku 2001:56). In Soviet times reindeer herding was seen only as the production of meat and hides, not a place for family life, leading to restrictions on women, children and retirees living on the NAO tundra and an active program of sedentarization (Tuisku 2002b). Despite the fact that many young men and women choose to remain in herding (Tuisku 2002b), the long-term impact has been to reduce the number of young women, and therefore young families, living on the tundra in NAO relative to YNAO (Tuisku 2001).

\section{DISCUSSION}

\section{Long-term resilience}

A core challenge in diagnosing why some SESs are sustainable whereas others collapse is the identification and analysis of relationships among multiple levels of these complex systems at different spatial and temporal scales (Ostrom 2009). Although ecologists know that ecosystem structure and function may take decades or centuries to fully respond to anthropogenic disturbance or environmental change, ecological studies almost exclusively examine ecosystem dynamics over intervals of a few months to a few years (Redman 2005, Fisher et al. 2009). Some SESs have persisted for hundreds of years, remaining in particular configurations that have withstood a variety of natural and social disturbances by managing to maintain flows of desired ecosystem goods and services within some tolerable bounds (Janssen et al. 2007). They have persisted by adapting their institutions to local natural variability. Examples of such adaptations include institutional arrangements associated with transhumance (Janssen et al. 2007). Analysis of SES persistence and resilience therefore requires a long-term perspective.

One of the key factors in the long-term resilience of Nenets SESs has clearly been the freedom to maintain relatively consistent spatial and temporal patterns of movement across extensive, ecologically intact landscapes as herders see fit within modern institutional constraints (Tuisku 2002b, Stammler 2005a). To be sure, a significant degree of artifice was imposed in Soviet times to accommodate minimum standards of collectivization within agricultural norms, and many families were suddenly separated from the territories of their ancestors. In their analysis of the robustness of pastoralist SESs to spatial and temporal variability, Janssen et al. (2007) noted that shepherds adapted by moving within the landscape in a certain order. According to them (p. 11), "activities that 
hinder this movement pattern on the landscape hit the vulnerable point of the transhumance system . . .thus, [it] is highly tolerant to seasonal variation by very specific institutional arrangements, but is extremely vulnerable to changes in access by social or physical barriers." In this context it is important to note that since NAO is so much smaller than YNAO, and contracts to only a few dozen $\mathrm{km}$ in its westernmost portion, long-term resilience may be reduced for those private or collective reindeer management units that experience spatial constraints.

\section{Barriers to access and sedentarization}

When considering Nenets SESs we must differentiate between ephemeral barriers to forage, such as heavily crusted snow, and the essentially permanent physical obstructions presented by pipelines, roads, and railways lacking suitable crossing points. In the case of rain-on-snow events, the absence of social and physical barriers, coupled with the aforementioned flexible institutional arrangements, allows herders to move with relative ease onto neighboring territories in search of accessible forage for their reindeer (Forbes and Stammler 2009, Bartsch et al. 2010). Janssen et al. (2007) argue that tailored adaptation to a particular type of variability can make a SES especially vulnerable to a change in that variability. Their reasoning (p. 13) is that, "when SESs with mobile resources and natural variability adapt themselves to specific movement patterns in the landscape, accompanied with timeand place-specific reciprocal arrangements, they become vulnerable to changes in accessibility." This scenario has been raised for Nenets SESs, and may be realized within the near future. The evidence suggests that the initial responses to restricted access will be localized, as only certain collective and privately managed herds are directly affected by pasture fragmentation and freshwater degradation (Forbes et al. 2009, Kumpula et al. 2010, 2011, 2012). However, such impacts will necessarily spread to the regional scale as the known development plans indicate a much larger network of pipelines, roads, and railways than exists at present. As this occurs herds must eventually merge either with their collectively managed tundra neighbors or be managed privately within the larger collective matrix. Either way, herders will have to share limited territories for forage and fishing resources. The final option is to leave the tundra to join the sedentary population in towns and cities.

The latter scenario is the least preferred alternative and the one most likely to threaten the long-term viability of Nenets SESs (Stammler 2008). This view concurs with that of Crane (2010:3), who argues that, "cultural transformation will be seen when shocks occur that cause ruptures or disjunctures in the connections between the social institutions, normative values, and the practices of day-to-day life." States seek to sedentarize mobile people and regularize the way they interact with resources in order "to make a society legible, to arrange the population in ways that simplify the classic state functions of taxation, conscription, and prevention of rebellion" (Scott 1998, Janssen et al. 2007:2). Demographically and territorially significant sedentarization policies successfully implemented on Yamal would constitute a classic example of the type of relatively abrupt change to be avoided. Imposed, top-down interventions tend not to recognize the original adaptive mechanisms inherent in local SESs (Janssen et al. 2007). For example, issues such as land-use, which in the pre-Soviet era used to be solved by kin or neighboring groups, are now regulated by the State to a greater degree in NAO (Tuisku 2001) relative to YNAO (Stammler 2005a, Forbes et al. 2009). State regulation may become prevalent in YNAO in the near future as more top-down initiatives emerge from the powerful combination of industrial and state imperatives. Of course, the 'ordering' of social interactions referred to by Scott (1998) has many potential benefits. Yet, any 'ordering' of society from above is necessarily schematic since it "ignores essential features of any real, functioning social order" (Scott 1998, Janssen et al. 2007:2).

Such a mismatch is clear when one compares, for example, state-sponsored maps of pasture resources in NAO (MLSE 2002) versus the actual manner in which these same territories are exploited on the ground. Pasture inventories have been a central component of the introduction of carrying capacity models in Nenets SESs since the early 1930s (Stammler $2005 a$, Rees et al. 2008), although the though the local bureaucracy to implement them was not created until after WWII. The maps show clear boundaries among respective collective management units within a larger matrix of seasonal pastures and provide detailed information on decadal trends (1993-2002) in the reserves of green and lichen forage. In reality, herders apparently move in a far more fluid manner in space and time, reflecting a combination of needs by both humans (access to suitable campsites, fishing/hunting/ gathering resources, sacred sites, etc.) and their reindeer (suitable forage, insect relief, protection from predators, etc.). Yet, in doing so they are simultaneously careful to pay nominal heed to the requirements of state bureaucracy. The situation supports Ostrom's (2011) observation that, in practice, people need to have their own rules to facilitate SES longevity, even if they purport an outward compliance with agricultural norms. Similar efforts can be seen among reindeer herding Sámi in Fennoscandia (Forbes et al. 2006, Laakso 2008).

\section{Flexible institutions and collective agency}

Underlying the various concerns surrounding ongoing and future herd management discussed above is the crucial issue of access to sizable territories. The movement of livestock over extensive areas is an example of an institutional arrangement that expressly addresses the multiple geographic scales of the underlying resource system (Janssen et al. 2007). Larger, collectively managed herds serve to help justify the persistence of a management regime based on agricultural norms emphasizing carrying capacity models. In this sense, 
one could argue that the former sovkhozi themselves have proven resilient. While there were always 'personal' reindeer during Soviet times, reindeer herding units have undergone substantial privatization in the post-Soviet era (Tuisku 2002b). A typology of the various subtypes of personal/private ownership is presented by Stammler (2005a:168-169), but he concedes that the situation is ever fluid and categorization can be elusive, even sometimes meaningless. Yet if the larger nominally collective units continue to functionally splinter and experienced nomads revert to smaller, privately managed herds, the increase in heterogeneity within the SESs would most likely facilitate resilience. Along these lines, it is worth noting that local experts on Yamal have suggested redirecting agricultural policies and institutions from a purely economic mode to a more cultural basis (Yuzhakov and Mukachev 2000 in Stammler 2002).

Control over herd demography and movement is central to resilience in both the short and the long terms. One the one hand, decreasing the tundra population of nomads in NAO via sedentarization during the Soviet era "made it possible to reduce the number of draught animals, which are male, and increase the number of calf-producing females, thus enabling higher meat production" (Tuisku 2001:45). On the other hand, without snowmobiles, which are expensive and lack fuel and spare parts, herders must increase the number of draught animals (Tuisku 2002b, Stammler 2005a, Forbes et al. 2009). Increasing the percentage of male draught reindeer correspondingly decreases females, resulting in fewer calves, which means a decrease in meat production. According to Tuisku (2002b), households decide the number of draught animals, and the number of females declined through the 1990s, the first decade of the post-Soviet era. Another area where herd demography and energetics come into play is responding to ice encasement of pastures. Rain-on-snow events leading to ice encasement typically require herds to move quickly onto neighboring territories to access forage and to date this has been possible within the existing management regime, at least on Yamal (Bartsch et al. 2010). Naturally, smaller herds have an advantage in such situations.

The fact that herders in both NAO and YNAO are allowed to use their own judgment and agency when it comes to herd demography, energetics and movement on a day-to-day basis, including in times of crisis (Tuisku 2001, 2002b, Stammler 2005a, 2011, Forbes et al. 2009, Bartsch et al. 2010), provides them with more flexibility than their Sámi counterparts in Fennoscandia. Given that Nenets herders are adept at adaptation and generally able to cope with the manifestations of extreme weather through collective agency, their vulnerability to projected climate change appears to be comparatively small (Rees et al. 2008, Forbes et al. 2009). Effective societal responses to environmental stress entail a combination of social memory and experimentation, enabling "innovation in the form of experimental recycling or reinvention of curated knowledge of past climate experience and of economic and sociopolitical strategies that previously provided solutions," which become "coded in the foundation legends, beliefs, and material cues that serve in turn to structure a society's perception of its environment" (Davidson 2010:1141).

\section{Stewardship and worldview}

Although overuse of some resources has occurred in the past (Krupnik 1993), and geobotanists consistently characterize the regions' rangelands as 'overgrazed' (Podkorytov 1995, Lavrinenko and Kulugina 2002, Kryazhimskii et al. 2011), the Nenets have practiced reindeer herding for several centuries by now without inflicting permanent damage to their environment (Tuisku 2002a). The theory and practice of stewardship is strongly interwoven with the Nenets worldview. According to Davidson (2010:1141), "cultural schemas provide mechanisms for selecting among a given pool of information and events for incorporation into social memory, and limiting the alternatives for social action to those accommodated by a particular worldview." Along these lines, Tuisku (2002c:102) argues that, "the careful herding of reindeer is a prerequisite for the people's well-being." She also notes that, "reindeer herders' vision of the future extends to several generations, and they want to ensure that future generations will be able to live on the land" (Tuisku 2002a:149). As such, herders do not use the same pastures year after year, and have consistently practiced their own system of campsite and pasture rotation within the outward confines of the Soviet and post-Soviet collective management regimes (Tuisku 2002c, Stammler 2005a). Conflict derives from the fact that while oil and gas developers routinely damage the environment (Forbes et al. 2001, 2009, Kumpula et al. 2011), reindeer herding depends on unbroken tundras and undisturbed vegetation. (Tuisku 2002a). Inevitably, some pessimism about the future therefore stems from the loss of control over land and the inability to mitigate terrestrial and freshwater degradation from industry (Tuisku 2002a, Forbes et al. 2009, Kumpula et al. 2011, 2012). "For herders, the crucial questions are how much pastureland they will lose and will they get any compensation" (Tuisku 2002a:151). Still, the Nenets worldview at it pertains to hydrocarbon extraction in both regions remains rather accommodating, although the scale of development in the very near future may become overwhelming for certain herding units (Tuisku 2003, Forbes et al. 2009, Kumpula et al. 2011). The spatial patchiness of development can affect attitudes in both positive and negative ways. In NAO, Tuisku (2003) notes that oil company charity has resulted in generally favorable attitudes by the villagers and the local newspaper. At the same time, contracts with oil companies have led to disparity among neighboring enterprises, e.g., Yerv vs. Kharp vs. Krasnoe. Enterprises without the benefits of oil development complain that young people are not willing to continue in herding. Yerv and Kharp 
are economically successful, while Vyucheiski is less well off (Tuisku 2002b).

According to Stammler (2010), the degree of stewardship described above extends well beyond herds and pasture vegetation to other elements of the SESs (see also Stammler 2011). Fish, for example, are almost as important as reindeer for tundra Nenets. He observes in some detail that, "Nenets nomads with a great deal of fishing activity have a profound knowledge of fish and maintain intimate connections with both the physical and spiritual spheres. Lakes or rivers with fish populations in winter are valued most and cared for. Not only should the lakes not be overfished, they also should not be underfished. Underfishing leads to a natural population crash, because the population becomes too large and consumes all the plants in the lakes, the oxygen content of the water decreases and as a consequence fish cannot survive there. There have been cases where all the fish in a lake died due to underfishing. So people, together with fish, are responsible for keeping lakes healthy. Here too, the perception is that people together with animals maintain the environment in a healthy state" (Stammler 2010:222-223), another example of collective action. The hunting of predators is similarly pragmatic, and the tendency is to let them be until specific action is deemed necessary. As one Nenets explained, there are a few wolf packs on Yamal and they generally take enough reindeer to sustain themselves without causing too much trouble. However, sometimes a single wolf can rampage and kill an inordinate number of reindeer in a short period of time, in which case the animal is likely to be hunted down. According to the same herder, the number of eagles fluctuates in response to lemming cycles. In years when eagle populations peak, herders will kill some to avoid excessive predation on calves (M. Okotetto, personal communication).

\section{Youth retention}

The displacement of children from the tundra in NAO in the 1960s and 70s was a painful process for many nomadic families (Tuisku 2001). In Nenets culture there has traditionally been a strict division of labor between the sexes, "but this is no longer possible in NAO because there are only a few nuclear families left" (Tuisku 2002c:101). This contrasts with the situation on Yamal, where large, nuclear families remain the norm (Ulvevadet and Klokov 2004, Stammler $2005 a$ ). Family size is different for various groups of Nenets, and it differs as well between sedentary families those that continue to lead a nomadic way of life. The average size of the nomadic families in YNAO in 2011 was 4.6 persons: 5.4 in Yamalsky district, among them 5.6 in the Yar-Salinsky sovhoz; 4.5 in the Tazovsky district, and 4.2 in the Priuralsky district). In the Tazovsky district, for example, the average Nenets family size is 4.3 persons; 3.7 in villages and 4.5 in the tundra (YNAO 2011). The Nenets families that live in villages often include nephews and grandchildren. The composition of nomadic families is more homogeneous since it includes the nuclear units consisting of parents, children, and typically some older relatives.

Concerning tundra household demographics, for 2011 in YarSale municipality there were 445 nomadic households consisting of 2496 registered people, of which 1343 (53.9\%) were of working age. In the same year average family size was 5.6 in the Yarsalinskii sovkhoz. Among people of working age $659(49 \%)$ were women. The number of Nenets females in all Nenets nomadic households in Yarsalinskii municipality was 1257 persons (50.3\%) (YNAO 2011). Children of nomadic families aged $6-16$ or so must attend boarding school for most of the year in one of the regional settlements. During the summer and for a month over the Christmas-New Year holiday they are part of their respective nomadic households. This time spent on the tundra is essential for the transfer of knowledge and skill sets needed if they are to eventually live permanently as nomads.

In NAO many obstacles remain preventing the return of family members to the tundra. This is a legacy of Soviet attitudes, which prevailed during the program of sedentarization. "A divided family and shared dwellings is considered a Soviet idea, whereas a family living together is part of the Nenets tradition" (Tuisku 2001:53). In particular, "the lack of an individual family dwelling or chum is one of the key reasons young women are not interested in returning to the tundra" (Tuisku 2001:54). However, there are some hopeful signs for the future since the attitude of modern local officials towards reindeer herding differs from the Soviet-era attitude. "If in Soviet times the nomadic way of life was seen as backward and people were prevented from living in the tundra by various regulations, today the tundra is accepted as a place to live for women and children. Many unemployed young people go to the tundra after finishing school: even though they do not get paid in the tundra, there are things to do and meat to eat" (Tuisku 2002b:203). According to one older herder, "When there are no women on the tundra, there are no children on the tundra. Children are tomorrow's herders, and you can't learn herding living in the village" (Tuisku 2001:55). The retention of a strong youth cohort committed to nomadism in the Yamal tundra is one of the striking contrasts with other reindeer herding regions, including NAO.

\section{CONCLUSION}

This article has reviewed empirical data on resilience in SESs from local and regional scale case studies of tundra nomads in NAO and YNAO. As Crane (2010) asks in relation to her African agropastoralist systems investigated, question remains as to whether or not the Nenets SES described here are rightfully described as resilient. The answer depends on the analytical frame through which a given SES is viewed, which is at least partly a function of the social position of the analyzer (Crane 2010). Davidson (2010:1145) argues that, "resilience itself should be understood as one of three possible 
responses to disturbance, with the other two being adaptation and transformation, and the researcher should not presume ipsofacto that resilience is necessarily the preferred response." Davidson (2010) further contends that adaptation to variability occurs over many generations by experimentation and learning and, as a consequence, may lead to the development of specialized institutions. Such adaptations refer to highly optimized complex systems that are robust within a certain range and type of variability, but may be sensitive to changes in these patterns of variability (Carlson and Doyle 2002). Janssen et al. (2007) hypothesize that many long-term SESs have developed a highly optimized tolerance or HOT reaction to a particular type of variability, but then become vulnerable to regime changes caused by many contemporary socialeconomical processes. In comparing neighboring Nenets SES subject to quite similar anthropogenic disturbance regimes, environmental change and socio-economics pressures over similar spatial and temporal scales we can draw some conclusions with clear relevance to cultural resilience.

While the structural complexity of both ecological and social systems can be conceived of in similar terms, the feedback processes associated with each are quite different: Social systems are unique in that the tendencies toward complexity, and the responses of individual organisms to those levels of complexity, are defined not solely by structural variables, but by agency (Davidson 2010). "Agency, in effect, defines an additional conceptual layer not present in ecological systems, and consequently not reflected in ecological theories of resilience. The components of ecosystems cannot consciously act. We are capable of recognizing risks, human-induced or otherwise, to our social systems and/or those things we value before they manifest, and thus we have the potential to take conscious, transformative steps to attenuate them." (Davidson 2010:1142). Although "many social theorists question whether collective agency is possible at all" (Davidson 2010:1144), the evidence presented here indicates that collective agency is indeed a crucial aspect of tundra Nenets SES sustainability (sensu Ostrom 2009). The evidence also points to Nenets culture as a key ingredient of the overall success (sensu Stammler 2002) of these SESs. The Yamal Nenets SES, in particular, has fared remarkably well in response to substantial shocks and pressures in recent decades (Forbes et al. 2009). Tundra nomadism in NAO has certainly suffered important setbacks during the late Soviet and postSoviet eras, yet has still not faced a deep crisis to the extent experienced in many other parts of northern Russia (Krupnik 2000, Tuisku 2001). One of the most significant problems in NAO compared to neighboring Yamal has been the prolonged absence of women and children from nomadism as a legacy of Soviet-era sedentarization. As Tuisku (2001:57) notes, for "the smooth running of tundra reindeer herding" the presence of women on the tundra is simply essential (see also Golovnev and Osherenko 1999), while the future of reindeer herding depends on the relatively consistent recruitment of children (Turi 2002, Ulvevadet and Klokov 2004). The analysis here thus reveals the central role of culture in Nenets SES persistence via the following: (i) an accommodating worldview with respect to environment, industrial development and the future; and (ii) a strong sense of stewardship, which manifests itself through individual as well as collective agency with positive implications for local and regional ecosystem services.

Herders in both NAO and YNAO have serious concerns about the progressive loss of pastures, campsites and sacred sites, poaching of reindeer and other wildlife, and wasteful fishing practices by gas and oil workers (Forbes et al. 2009, Kumpula et al. 2011, 2012). It remains to be seen if there will be conflicts between privately managed and collective herds as territories are increasingly fragmented by infrastructure, rangelands inevitably contract and the competition grows for unlimited access to pastures and the most productive fishing lakes and rivers. These issues are likely to remain to the fore, relative to climate change, for the foreseeable future (Rees et al. 2008, Forbes and Stammler 2009). Although for Nenets significant environmental change from year to year is simply an accepted part of their nomadic existence on the tundra, funding and political institutions appear likely to continue focusing on 'change' in its different forms. For example, during 20112013 Sweden's Chairmanship of the Arctic Council has overlapped with the beginning the Arctic Resilience Report (ARR) and the Adaptation Action for a Changing Arctic (AACA). ARR and AACA are among the Arctic Council's key successor activities to the Arctic Climate Impact Assessment (ACIA 2005) and Snow, Water, Ice and Permafrost in the Arctic (SWIPA 2011). Given the prevalence of modeling in the analysis of ecological systems, resilience and land change science (Carpenter et al. 2005, Turner et al. 2007), some suggest that cultural values, practices and local knowledge can and should be integrated into systems models, inasmuch as they direct behavior in predictable ways and may be generalized (Crane 2010, Hovelsrud et al. 2011). Such integration is perhaps too much to expect anytime soon. However, explicitly acknowledging the central nature of cultural imperatives and collective agency is clearly an important first step when planning future analyses of longterm resilience in Nenets and similarly persistent SESs.

Responses to this article can be read online at: http://www.ecologyandsociety.org/issues/responses. php/5791

\section{Acknowledgments:}

This paper is a contribution of the Rangifer synthesis project funded by the National Science Foundation Office of Polar 
Programs (Grant 0531200). Additional support was provided by the National Aeronautics and Space Administration (grants NNG6GE00A and NNX09AK56G), the Academy of Finland's Russia in Flux program through the ENSINOR project (decision 208147) and the Arctic Operational Platform (ARCOP). I could not have undertaken this analysis without the extensive social anthropological fieldwork conducted primarily by Drs. Florian Stammler and Nina Meschtyb. They have freely shared their findings and discussed them at length with me for the past decade. However, any failings in the interpretations of these data are mine alone. Similarly, I gratefully acknowledge the time and effort spent by the many Nenets reindeer herders who hosted us in their chums in all seasons and the oil and gas workers, local and regional administrators who went out of their way to accommodate our various teams, often under trying conditions. This research would not have been possible without their high levels of trust, enthusiasm and professionalism. Without ever using such language, collectively they have patiently mentored us a great deal in the practicalities and endless nuances of cultural resilience. Finally, I thank the two anonymous reviewers who provided extremely constructive critiques of earlier versions of the manuscript.

\section{LITERATURE CITED}

ACIA. 2005. Arctic Climate Impact Assessment. Cambridge University Press, Cambridge, UK.

Anderson, D. G. 2006. Is Siberian reindeer herding in crisis? Living with reindeer fifteen years after the end of state socialism. Nomadic Peoples NS 10(2):87-104. http://dx.doi. org/10.3167/np.2006.100206

Bartsch, A., T. Kumpula, B. C. Forbes, and F. Stammler. 2010. Detection of snow surface thawing and refreezing using QuikSCAT: implications for reindeer herding. Ecological Applications 20:2346-2358. http://dx.doi.org/10.1890/09-1927.1

Bulygina, O. N., V. N. Razuvaev, and N. N. Korshunova. 2009. Changes in snow cover over Northern Eurasia in the last few decades. Environmental Research Letters 4. http://dx.doi. org/10.1088/1748-9326/4/4/045026

Bulygina, O. N., P. Y. Groisman, V. N. Razuvaev, and N. N. Korshunova. 2011. Changes in snow cover characteristics over Northern Eurasia since 1966. Environmental Research Letters 6 doi:10.1088/1748-9326/6/4/045204. http://dx.doi. org/10.1088/1748-9326/6/4/045204.

Callaghan, T. V., M. Johansson, R. D. Brown, P. Ya. Groisman, N. Labba, V. Radionov, R. G. Barry, R. S. Bradley, S. Blangy, O. N. Bulygina, T. R. Christensen, R. L. H. Essery, B. C. Forbes, M. C. Forchhammer, V. N. Golubev, R. . Honrath, G. P. Juday, A. V. Meshcherskaya, G. K. Phoenix, J. Pomeroy, A. Rautio, D. A. Robinson, N. M. Schmidt, M. C. Serreze, V. P. Shevchenko, A. I. Shiklomanov, A. B.
Shmakin, P. Sköld, M. Sturm, M.-K. Woo, and E. F. Wood. 2011. Multiple effects of changes in Arctic snow cover. Ambio 40:32-45. http://dx.doi.org/10.1007/s13280-011-0213-x

Carlson, J. M., and J. Doyle. 2002. Complexity and robustness. Proceedings of the National Academy of Sciences USA 99:2538-2545.

Carpenter, S. R., F. Westley, and M. G. Turner. 2005. Surrogates for resilience of social-ecological systems. Ecosystems 8:941-944. http://dx.doi.org/10.1007/s10021-005-0170ע

Chapin, F. S. III, G. R. Shaver, A. E. Giblin, K. J. Nadelhoffer, and J. A. Laundre. 1995. Responses of arctic tundra to experimental and observed changes in climate. Ecology 76:694-711. http://dx.doi.org/10.2307/1939337

Chapin, F. S. III, S. R. Carpenter, G. P. Kofinas, C. Folke, N. Abel, W. C. Clark, P. Olsson, D. M. Stafford Smith, B. Walker, O. R. Young, F. Berkes, R. Biggs, J. M. Grove, R. L. Naylor, E. Pinkerton, W. Steffen, and F. J. Swanson. 2010. Ecosystem stewardship: sustainability strategies for a rapidly changing planet. Trends in Ecology and Evolution 25(4):241-249.

Cornelissen, J. H. C. et al. 2001. Global change and arctic ecosystems: is lichen decline a function of increases in vascular plant biomass? Journal of Ecology 89:984-994.

Crane, T. A. 2010. Of models and meanings: cultural resilience in social-ecological systems. Ecology and Society 15(4):19. [Online] URL: http://www.ecologyandsociety.org/vol15/ iss4/art19/

Davidson, D. J. 2010. The applicability of the concept of resilience to social systems: some sources of optimism and nagging doubts. Society and Natural Resources 23:1135-1149. http://dx.doi.org/10.1080/08941921003652940

Fisher, C. T., J. B. Hill, and G. M. Feinman, editors. 2009. The archaeology of environmental change: socionatural legacies of degradation and resilience. University of Arizona Press, Tuscon, USA.

Forbes, B. C., and T. Kumpula 2009. The ecological role and geography of reindeer (Rangifer tarandus) in northern Eurasia. Geography Compass 3/4:1356-1380. http://dx.doi. org/10.1111/j.1749-8198.2009.00250.x

Forbes, B. C., and F. Stammler. 2009. Arctic climate change discourse: the contrasting politics of research agendas in the West and Russia. Polar Research 28:28-42. http://dx.doi. org/10.1111/j.1751-8369.2009.00100.x

Forbes, B. C., J. J. Ebersole, and B. Strandberg. 2001. Anthropogenic disturbance and patch dynamics in circumpolar arctic ecosystems. Conservation Biology 15:954 -969. http://dx.doi.org/10.1046/j.1523-1739.2001.015004954. $\underline{\mathrm{X}}$ 
Forbes, B. C., M. Bölter, L. Müller-Wille, J. Hukkinen, F. Müller, N. Gunslay, and Y. Konstantinov, editors. 2006. Reindeer management in northernmost Europe: linking practical and scientific knowledge in social-ecological systems. Ecological Studies 184. Springer-Verlag, Berlin, Germany.

Forbes, B. C., F. Stammler, T. Kumpula, N. Meschtyb, A. Pajunen, and E. Kaarlejärvi. 2009. High resilience in the Yamal-Nenets social-ecological system, West Siberian Arctic, Russia. Proceedings of the National Academy of Sciences USA 106:22041-22048. http://dx.doi.org/10.1073/ pnas.0908286106

Forbes, B. C., F. Stammler, T. Kumpula, N. Meschtyb, A. Pajunen, and E. Kaarlejärvi. 2011. Yamal reindeer breeders, gas extraction, and changes in the environment: adaptation potential of nomad economy and its limits (in Russian). Environmental Planning and Management 1(12)C:52-68.

Forbes, B.C ., M. Macias Fauria, and P. Zetterberg. 2010. Russian Arctic warming and 'greening' are closely tracked by tundra shrub willows. Global Change Biology 16:1542-1554. http://dx.doi.org/10.1111/j.1365-2486.2009.02047.x

Golovnev A. V., and G. Osherenko. 1999. Siberian survival: the Nenets and their story. Cornell University Press, Ithaca, New York, USA.

Gray, P., and F. Stammler. 2002. Siberia caught between collapse and continuity. Max Planck Research 3/2002:55-61.

Hovelsrud, G. K., B. Poppel, B. E. H. van Oort, and J. D. Reist. 2011. Arctic societies, cultures, and peoples in a changing cryosphere. Pages 10-1 - 10-39 in Snow, Water, Ice, Permafrost in the Arctic (SWIPA): Climate change and the cryosphere. Arctic Monitoring and Assessment Programme, Oslo, Norway. http://dx.doi.org/10.1007/s13280-011-0219-4

Ingold, T. 1980. Hunters, pastoralists and ranchers. Cambridge University Press, Cambridge, UK. http://dx.doi. org/10.1017/CBO9780511558047

Janssen, M. A., J. M. Anderies, and E. Ostrom. 2007. Robustness of social-ecological systems to spatial and temporal variability. Society and Natural Resources 20:1-16.

Jernsletten, J-L. and K. Klokov, editors. 2002. Sustainable reindeer husbandry. Centre for Saami Studies, Troms $\varnothing$, Norway.

Krupnik, I. 1993. Arctic adaptations: native whalers and reindeer herders of northern Eurasia. University Press of New England, Dartmouth, New Hampshire, USA.

Krupnik, I. 2000. Reindeer pastoralism in modern Siberia: research and survival in the time of crash. Polar Research 19:49-56. http://dx.doi.org/10.1111/j.1751-8369.2000.tb00327. $\underline{\mathrm{x}}$
Kryazhimskii, F. V., K. V. Maklakov, L. M. Morozova, and S. N. Ektova. 2011. System analysis of biogeocenoses of the Yamal Peninsula: simulation of the impact of large-herd reindeer breeding on vegetation. Russian Journal of Ecology 42(5): 351-361. http://dx.doi.org/10.1134/S1067413611050092

Kumpula, T., B. C. Forbes, and F. Stammler. 2010. Remote sensing and local knowledge of hydrocarbon exploitation: the case of Bovanenkovo, Yamal Peninsula, West Siberia, Russia. Arctic 63:165-178.

Kumpula, T., A. Pajunen, E. M. Kaarlejärvi, B. C. Forbes, and F. Stammler. 2011. Land use and land cover change in arctic Russia: ecological and social implications of industrial development. Global Environmental Change 21:550-562. http://dx.doi.org/10.1016/j.gloenvcha.2010.12.010

Kumpula, T., B. C. Forbes, F. Stammler, and N. Meschtyb. 2012. Dynamics of a coupled system: multi-resolution remote sensing in assessing social-ecological responses during 25 years of gas field development in Arctic Russia. Remote Sensing 4: 1046-1068. http://dx.doi.org/10.3390/rs4041046

Laakso, A. M. 2008. The shadow field of reindeer management: a case study from Finland. Acta Borealia 25 (2):138-159. http://dx.doi.org/10.1080/08003830802496703

Lavrinenko, O., and E. Kulugina. 2002. Use of the state natural reserve in the Nenets district as reindeer pastures: inventory of lichens. Pages 80-88 in P. Soppela, W. Ruth, B. Åhman, and J.A. Riseth, editors. Reindeer as a keystone species in the north: biological, cultural and socio-economic aspects. Arctic Centre Reports 38, University of Lapland, Rovaniemi, Finland.

Macias Fauria, M., B. C. Forbes, P. Zetterberg and T. Kumpula. 2012. Eurasian Arctic greening reveals teleconnections and the potential for structurally novel ecosystems. Nature Climate Change 2:613-618. http://dx.doi. org/10.1038/nclimate1558

McIntosh, R. J., J. A. Tainter, and S. K. McIntosh. 2000. Climate, history, and human action. Pages 1-44 in R. J. McIntosh, J. A. Tainter, and S. K. McIntosh, editors. The way the wind blows: climate history, and human action. Columbia University Press, New York, USA.

Meschtyb, N. A., B. C. Forbes, and P. Kankaanpää. 2005. Social Impact Assessment along Russia's Northern Sea Route: petroleum transport and the Arctic Operational Platform (ARCOP). Arctic InfoNorth 58:322-327.

MLSE. 2002. Land survey of reindeer breeding farms: SPK Coop "ERV". 1: 200000 map series (in Russian). Murmansk Land Surveyor Enterprise, Murmansk, Russia.

NASA-GISS, 2013. Surface Temperature Analysis. National Aeronautics and Space Administration/Goddard Institute for 
Space Studies, USA. [Online] URL: http://data.giss.nasa.gov/ gistemp/maps

Ostrom, E. 2009. A general framework for analyzing the sustainability of social-ecological systems. Science 325:419-422. http://dx.doi.org/10.1126/science.1172133

Ostrom, E. 2011. Thinking about the future: a socialecological systems approach to sustainability. Plenary address to Resilience 2011: Second International Science and Policy Conference, 11-16 March 2011, Tempe, Arizona, USA. [Online] URL: http://csid.asu.edu/resilience-2011/invitedspeakers/pdf/Ostrom.pdf

Podkorytov, F. M. 1995. Reindeer herding on Yamal (in Russian). Leningradskoi Atomoi Electrostantsii, Sosnovyi Bor, Russia.

Redman, C. L. 2005. Resilience theory in archaeology. American Anthropologist 107:70-77. http://dx.doi.org/10.1525/ aa.2005.107.1.070

Rees W. G., F. M. Stammler, F. S. Danks, and P. Vitebsky. 2008. Vulnerability of European reindeer husbandry to global change. Climatic Change 87:199-217. http://dx.doi. org/10.1007/s10584-007-9345-1

Scott, J. C. 1998. Seeing like a state. Yale University Press, New Haven, Connecticut, USA.

Smith, L. C., Y. Sheng, G. M. MacDonald, and L. D. Hinzman. 2005. Disappearing Arctic lakes. Science 308:1429. http://dx. doi.org/10.1126/science.1108142

Ssorin-Chaikov, Nikolai V. 2003. The social life of the state in subarctic Siberia. Stanford University Press, Stanford, California, USA.

Stammler, F. 2002. Success at the edge of the land: present and past challenges for reindeer herders of the West-Siberian Yamal-Nenets Autonomous Okrug. Nomadic Peoples 6 (2):51-71.

Stammler, F. 2005a. Reindeer nomads meet the market: culture, property and globalization at the 'End of the land'. Lit Verlag, Münster, Germany.

Stammler, F. 2005b. The Obshchina movement in Yamal: defending territories to build identities? Pages 109-134 in E. Kasten, ed. Rebuilding identities: pathways to reform in postsoviet Siberia. Dietrich Reimer Verlag, Berlin.

Stammler, F. 2008. Opportunities and threats for mobility: reindeer nomads of the West Siberia coastal zone (Yamal) respond to changes (in Russian). Environmental Planning and Management 3-4(8-9):78-91.

Stammler, F. 2009. Mobile phone revolution in the tundra? Technological change among Russian reindeer nomads. Pages
47-78 in A. Ventsel, editor. Generation $P$ in the Tundra. Folklore 41. Estonian Literary Museum, Tallinn, Estonia. [Online] URL: http://www.folklore.ee/folklore/vol41/stammler. pdf

Stammler, F. 2010. Animal diversity and its social significance among Arctic pastoralists. Pages 215-243 in F. Stammler and H. Takakura, editors. Good to eat, good to live with: nomads and animals in northern Eurasia and Africa. Northeast Asia Studies Series 11. Center for Northeast Asia Studies, Tohoku University, Sendai, Japan.

Stammler, F. 2011. Oil without conflict? The anthropology of industrialization in northern Russia. Pages 243-269 in A. Behrends, S. R. Reyna and G. Schlee, editors. Crude domination: an anthropology of oil. Berghahn Books, Oxford.

Stammler, F., and V. Peskov. 2008. Building a 'Culture of Dialogue' among stakeholders in North-West Russian oil extraction. Europe-Asia Studies 5:831-849. http://dx.doi. org/10.1080/09668130802085182

Stammler, F., and E. Wilson. 2006. Dialogue for development: an exploration of relations between oil and gas companies, communities and the state. Sibirica 5(2):1-42. http://dx.doi. org/10.3167/136173606780490739

SWIPA. 2011. Snow, Water, Ice, Permafrost in the Arctic (SWIPA): Climate change and the cryosphere. Arctic Monitoring and Assessment Programme, Oslo, Norway.

Tuisku, T. 2001. The displacement of Nenets women from reindeer herding and the tundra in the Nenets Autonomous Okrug, northwestern Russia. Acta Borealia 2:41-60. http://dx. doi.org/10.1080/08003830108580525

Tuisku, T. 2002a. Nenets reindeer herding and industrial exploitation in northwest Russia. Human Organization 61:147-153.

Tuisku, T. 2002b. Transition period in the Nenets Autonomous Okrug: changing and unchanging life of Nenets people. Pages 189-206 in E. Kasten, editor. People and the land: pathways to reform in post-Soviet Siberia. Dietrich Reimer Verlag, Berlin, Germany.

Tuisku, T. 2002c. Reindeer herding. Pages 100-105 in I. Lehtinen, editor. Siberia, life on the taiga and tundra. National Board of Antiquities, Jyväskylä, Finland.

Tuisku, T. 2003. Surviving in the oil age: co-existence of the reindeer herding and petroleum development. Pages 449-461 in R. O. Rasmussen and N. E. Koroleva, editors. Social and environmental impacts in the North. Kluwer, Dordrecht, The Netherlands.

Turi, J. M. 2002. The world reindeer livelihood: current situation, threats and possibilities. Pages $70-75$ in $\mathrm{S}$. 
Kankaanpää, editor. Northern timberline forests: environmental and socio-economic issues and concerns. Finnish Forest Research Institute, Jyväskylä, Finland.

Turner, B. L. II, E. F. Lambin, and A. Reenberg. 2007. The emergence of land change science for global environmental change and sustainability. Proceedings of the National Academy of Sciences USA 104:20666-20671. http://dx.doi. org/10.1073/pnas.0704119104

Ulvevadet, B., and K. Klokov. 2004. Family-based reindeer herding and hunting economies, and the status and management of wild reindeer/caribou populations. Arctic Council/Centre for Saami Studies, Troms $\varnothing$, Norway.

Vitebsky, P. 2005. Reindeer People. Living with animals and spirits in Siberia. Harper Collins, London.

Vitebsky, P., and S. Wolfe. 2001. The separation of the sexes among Siberian reindeer herders. Pages 81-95 in A. Low and S. Tremayne, editors. Sacred custodians of the Earth? Women, spirituality and the environment. Berghahn Books, Oxford.

Xu, L., R. B. Myneni, F. S. Chapin III, T. V. Callaghan, J. E. Pinzon, C. J. Tucker, Z. Zhu, J. Bil, P. Ciais, H. Tømmervik, E. S. Euskirchen, B. C. Forbes, S. L. Piao, B. T. Anderson, S. Ganguly, R. R. Nemani, S. J. Goetz, P. S. A. Beck, A. G. Bunn, C. Cao, and J. C. Stroeve. 2013. Temperature and vegetation seasonality diminishment over northern lands. Nature Climate Change http://dx.doi.org/10.1038/nclimate1836

YNAO. 2011. Information on the number of nomadic population at the areas inhabited by indigenous peoples of the North on 1 January, 2011 in the Yamal-Nenets Autonomous Okrug (in Russian). Report from Regional Department of the State Statistics, Yamal-Nenets Autonomous Okrug, Salekhard, Russia.

Yuzhakov, A. A. 2006. The Nenets aboriginal breed of northern reindeer (in Russian). Red North Publishers, Salekhard, Russia.

Zeng, H., G. S. Jia, and B. C. Forbes, 2013. Response of phenological shifts to climate and anthropogenic factors as detected from multi-satellite data. Environmental Research Letters 8. http://dx.doi.org/10.1088/1748-9326/8/3/035036

Zenko, M. A. 2004. Contemporary Yamal: ethncoecological and ethnosocial problems. Anthropology \& Archaeology of Eurasia 42:7-63. 